\title{
PENINGKATAN KEMAMPUAN PEMECAHAN MASALAH MATEMATIKA SISWA KELAS VIII-A SMP NEGERI 1 SAWAN MELALUI PENERAPAN MODEL PEMBELAJARAN CREATIVE PROBLEM SOLVING BERBANTUAN PORTOFOLIO
}

\author{
N. K. M. S. Dewi ${ }^{1}$, M. Sugiarta ${ }^{2}$, I. G. P. Suharta ${ }^{3}$ \\ Jurusan Pendidikan Matematika,Universitas Pendidikan Ganesha Singaraja, Indonesia \\ e-mail: menasintadewi@gmail.com, madesugiarta54@gmail.com, igpsuharta@yahoo.com
}

\begin{abstract}
Abstrak
Penelitian ini bertujuan untuk mengetahui: (1) peningkatan kemampuan pemecahan masalah matematika siswa kelas VIII-A SMP Negeri 1 Sawan dan (2) respon siswa terhadap penerapan model pembelajaran creative problem solving berbantuan portofolio. Jenis penelitian ini adalah penelitian tindakan kelas yang dilaksanakan dalam tiga siklus. Subjek penelitian ini adalah siswa kelas VIII-A SMP Negeri 1 Sawan sebanyak 32 orang siwa pada semester genap Tahun Ajaran 2017/2018. Data kemampuan pemecahan masalah siswa dikumpulkan melalui tes kemampuan pemecahan masalah dan data tentang respon siswa dikumpulkan menggunakan angket. Data yang telah terkumpul selanjutnya dianalisis secara deskriptif. Hasil penelitian ini menunjukkan bahwa rata-rata nilai kemampuan pemecahan masalah siswa mengalami peningkatan dari siklus ke siklus, pada siklus I, siklus II, dan siklus III berturut-turut yaitu: 70,$05 ; 75,26 ; 81,08$. Peningkatan optimal pada siklus III terjadi karena guru lebih menekankan pada pertanyan arahan dalam mengemukakan gagasan-gagasan, memberikan kebebasan kepada siswa untuk menyelesaikan permasalahan sesuai dengan cara mereka sendiri, memberikan kesempatan lebih banyak kepada siswa untuk menyampaikan pendapat, penggunaan portofolio untuk membantu siswa lebih terlatih dalam menyelesaikan soal non-rutin dengan pemberian feedback (komentar) yang diberikan guru sehingga siswa mengetahui kekurangannya untuk segera diperbaiki, serta memberikan bimbingan dan motivasi kepada siswa. Selain itu, respon siswa terhadap penerapan model pembelajaran creative problem solving berbantuan portofolio tergolong positif dengan rata-rata respon siswa sebesar 57,41
\end{abstract}

Kata kunci: kemampuan pemecahan masalah, model creative problem solving dan portofolio.

\begin{abstract}
This research was intended to describe: (1) improvement mathematical problem solving ability of students in SMP Negeri 1 Sawan and (2) students response to the application of creative problem solving model assisted portfolio. This type of research is a classroom action research conducted in three. The subjects of this research were students of VIII-A class in SMP Negeri 1 Sawan which consists 32 students in the even semester of the academic year 2017/2018. The data of mathematical problem solving ability were collected by using mathematical problem solving tests and the data of students responses were collected by questionnaire. The data that has been collected is the alayzed descriptively. The results of this research show that the average value of problem solving ability of students has increased from cycle to cycle, in cycle I, cycle II, and cycle III respectively: 70,05; 75,26; 81,08. Optimal improvement in cycle III because teachers focus more on questions directed in expressing ideas, giving students the freedom to solve problems according to their own way, giving students more opportunities to express their opinions, the use of portfolios to help students are better trained in solving non-routine problems by giving feedback (comments) provided by the teacher so that students know the shortcomings to be repaired immediately, and provide guidance and motivation to students. In addition, students responses to the application of creative problem solving learning model assisted portfolio was positif with the average student response of 57,41 .
\end{abstract}

Keywords: problem solving ability, creative problem solving model, and portfolio. 


\section{PENDAHULUAN}

Suyatno (2009) mengatakan bahwa pembelajaran hendaknya dimulai dengan permasalahan yang aktual, autentik, relevan, dan bermakna bagi siswa. Mengajar matematika tidak hanya membuat siswa menguasai materi tetapi juga hendaknya mampu meningkatkan kemampuan siswa dalam memecahkan masalah karena kemampuan ini sangat diperlukan siswa, terkait dengan kebutuhan siswa untuk memecahkan masalah yang dihadapinya di kehidupan nyata. Penting-nya kemampuan pemecahan masalah ditegaskan dalam National Council of Teachers of Mathematics (NCTM, 2000) menyatakan bahwa pemecahan masalah merupakan bagian integral dalam pembelajaran matematika sehingga hal tersebut tidak boleh dilepaskan dari pembelajaran matematika. Meskipun kemampuan pemecahan masalah memiliki peranan yang sangat penting, namun kenyataannya di sekolah masih belum sesuai dengan apa yang diharapkan.

Permasalahan ini terdapat di SMP Negeri 1 Sawan ketika peneliti melakukan observasi di sekolah tersebut. Peneliti memperoleh data dari guru matematika kelas VIII-A SMP Negeri 1 Sawan yaitu data hasil ulangan tengah semester (UTS) semester ganjil tahun ajaran 2017/2018 yang berjumlah 32 orang. Berdasarkan data tersebut diperoleh persentase ketuntasan belajar siswa hanya $43,75 \%$ dengan KKM 70 . Hal ini mengindikasikan bahwa siswa masih mengalami permasalahan pada mata pelajaran matematika. Dari hasil wawancara dengan guru matematika dan observasi di kelas, diperoleh informasi bahwa masih banyak siswa yang memiliki kesulitan dalam menyelesaikan masalah matematika. Siswa juga masih sulit menentukan solusi yang tepat dari permasalahan yang diberikan. Kesulitan ini terjadi karena siswa masih terpaku pada contoh-contoh penyelesaian yang diberikan oleh guru. Selain itu, peneliti mendapatkan informasi dari guru bahwa rata-rata skor siswa pada materi bangun ruang sisi datar tahun sebelumnya masih berada dibawah KKM dengan KKM yaitu 75. Rata-rata skor siswa pada materi bangun ruang sisi datar tahun ajaran 2016/2017 yaitu 61. Dari hal ini dapat dilihat bahwa terjadi permasalahan pada pembelajaran materi bangun ruang sisi datar.

Berdasarkan wawancara dengan siswa, siswa lebih senang untuk me-ngerjakan soalsoal yang bersifat rutin dan siswa kurang tertarik untuk mengerjakan soal dalam bentuk cerita. $\mathrm{Hal}$ ini menyebabkan pem-belajaran matematika kurang bermakna. Selain itu, cukup banyak siswa yang bermasalah dalam me-rumuskan masalah matematika dan me-ngubahnya ke dalam bentuk kalimat matematika. Hal ini terjadi karena siswa kurang terbiasa menghadapi soal non-rutin.

Setelah melakukan observasi dan wawancara, untuk memperkuat asumsi bahwa kelas VIII-A terjadi permasalahan pada kemampuan pemecahan masalah matematika, peneliti memberikan tes awal kemampuan pemecahan masalah kepada siswa untuk mengukur kemampuan awal siswa dalam memecahkan masalah matematika.

Berdasarkan tes awal, menunjukkan bahwa sebagian besar siswa tidak membuat perencanaan dengan baik dan masih belum mampu memilih strategi yang tepat dalam memecahkan permasalahan yang diberikan. Selain itu, siswa belum terbiasa menyusun rencana untuk menyelesaikan masalah dan mengubah informasi yang ada ke dalam kalimat matematika. Kecenderungan siswa ketika memecahkan masalah adalah mereka berpatokan pada pola penyelesaian contoh soal yang diberikan guru dan menyele-saikannya tanpa diimbangi dengan pengecekan jawaban (tidak memuat simpulan). Meskipun siswa telah mampu melakukan perhitungan dengan tepat tetapi hasil yang diperoleh masih belum mampu menjawab permasalahan yang diberikan.

Hal yang dilakukan untuk mengatasi permasalahan tersebut agar tidak berkelanjutan maka perlu diterapkan model pembelajaran yang tepat dan sesuai dengan materi yang disampaikan sehingga permasalahan terhadap kemampuan pe-mecahan masalah 
matematika siswa dapat diatasi. Pada penelitian ini peneliti me-nerapkan model Creative Problem Solving berbantuan portofolio. Model pembelajaran creative problem solving adalah suatu model pembelajaran yang lebih menekankan pada keterampilan dalam menyelesaikan suatu permasalahan yang diikuti dengan penguatan kreativitas (Pepkin, 2004).

Pemilihan model ini berdasarkan hasil observasi yang telah dilakukan bahwa kemampuan siswa masih kurang dalam membuat perencanaan pemecahan masalah matematika dan belum mampu memilih strategi yang tepat untuk menyelesaikan masalah matematika. Dengan menerapkan model pembelajaran ini, siswa akan menjadi lebih terampil karena mempunyai langkah kerja yang lebih tersusun dari awal. Suyatno (2009:66) menyatakan bahwa model pembelajaran creative problem solving merupakan variasi dari pembelajaran dengan pemecahan masalah melalui teknik sistematik dalam mengorganisasikan gagasan kreatif untuk menyelesaikan suatu permasalahan.

Model pembelajaran creative problem solving ini terdiri empat tahapan yaitu: (1) klarifikasi masalah. (2) pengungkapan pendapat. (3) evaluasi dan pemilihan. (4) implementasi. Menurut Djamarah dkk (2006), pembelajaran dengan pemecahan masalah dapat membuat pendidikan sekolah menjadi lebih relevan dengan kehidupan khususnya dengan dunia kerja, proses belajar mengajar melalui pemecahan masalah dapat membiasakan para siswa menghadapi dan memecahkan masalah secara terampil dan model pembelajaran creative problem solving dapat merangsang pengembangan kemampuan berpikir siswa secara kreatif dan menyeluruh.

Model creative problem solving ini dibantu dengan portofolio. Portofolio adalah kumpulan informasi yang dapat berupa kumpulan seluruh karya siswa dalam kurun waktu tertentu yang menunjukkan perkembangan kemampuan siswa (Permendikbud, 2013). Portofolio dalam penelitian ini digunakan sebagai pendukung untuk meningkatkan kemampuan pemecahan masalah siswa karena siswa dapat berlatih untuk menyelesaikan soal pemecahan masalah dengan lebih terstruktur sesuai dengan caranya masing-masing. Selain itu, portofolio dapat mengembangkan keahlian siswa untuk menilai diri sendiri dan memberikan kesempatan bagi siswa untuk melakukan refleksi perkembangan dirinya karena guru dalam memeriksa portofolio siswa disertakan dengan komentar atau feedback (Febru, 2011). Penerapan model creative problem solving berbantuan portofolio diyakini mampu membuat siswa aktif, kreatif, antusias dalam mengikuti pem-belajaran dan mampu menanamkan kesadaran siswa untuk lebih meningkatkan dan memantapkan kemampuan pemecahan masalah matematika yang mereka miliki.

Hal ini juga di dukung oleh beberapa hasil penelitian yang relevan diantaranya yaitu: (1) Hasil penelitian yang dilakukan oleh I Made Budiadnyana dimana model creative problem solving berpengaruh positif terhadap kemampuan pemecahan masalah matematika dan sikap matematika peserta didik. (2) Hasil penelitian Putu Rini Handayani yaitu asesmen portofolio online berpengaruh positif terhadap kemampuan pemecahan masalah matematika.

Adapun tujuan dari penelitian ini adalah untuk (1) Mendeskripsikan peningkatan kemampuan pemecah-an masalah matematika siswa kelas VIII-A di SMP Negeri 1 Sawan melalui penerapan model pembelajaran creative problem solving berbantuan portofolio . (2) Mengetahui respon siswa terhadap penerapan model pembelajaran creative problem solving berbantuan portofolio.

\section{METODE}

Jenis penelitian yang digunakan adalah Penelitian Tindakan Kelas (classroom action research) yang bertujuan untuk meningkatkan dan memperbaiki proses pembelajaran di kelas VIII-A SMP Negeri 1 Sawan yaitu ke-mampuan pemecahan masalah matematika siswa. PTK yang digunakan adalah model Kurt Lewin. Penelitian ini dilaksanakan dalam tiga siklus. Menurut Kurt Lewin (dalam McNiff, 2002) tiap siklus terdiri dari (1) perencanaan tindakan, (2) pe-laksanaan tindakan, (3) observasi/ evaluasi, dan (4) refleksi. Data kemampuan 
pemecahan masalah matematika dan respon siswa dikumpulkan kemudian dianalisis menggunakan teknik analisis deskriptif.

\section{HASIL DAN PEMBAHASAN}

\section{HASIL PENELITIAN}

Pada tahap refleksi awal, setelah melakukan wawancara dan observasi. Peneliti memberikan tes awal kemampuan pemecahan masalah berbentuk soal uraian. Dari hasil analisis data kemampuan pemecahan masalah matematika yang dimiliki siswa sebelum pelaksanaan tindakan terlihat bahwa nilai terendah adalah 33.3 dan nilai tertinggi adalah 86,11 . Banyaknya siswa yang Banyaknya siswa yang memperoleh nilai di bawah KKM (70) sebanyak 19 orang dan persentase ketuntasan belajar hanya $40.63 \%$. Grafik sebaran tes awal kemampuan pemecahan masalah matematika siswa kelas VIII-A sebelum pelaksanaan tindakan penelitian disajikan dalam Gambar 1.1:

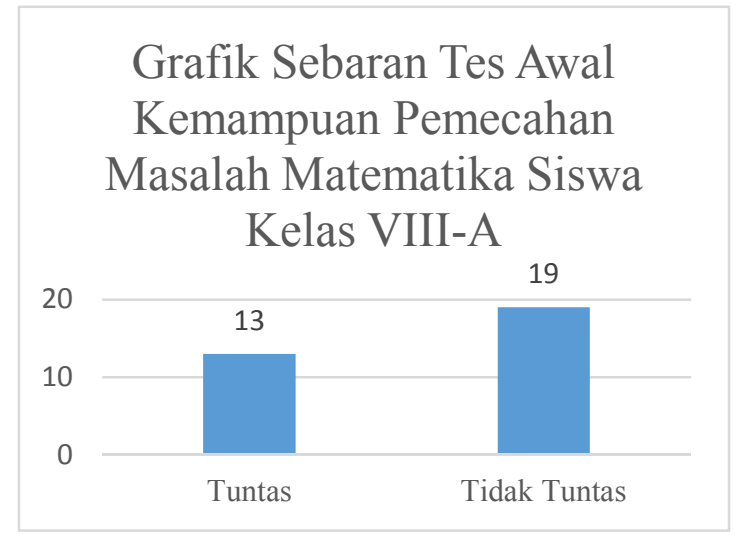

Gambar 1.1. Grafik Sebaran Tes Awal Kemampuan Pemecahan Masalah Matematika Siswa Kelas VIII-A

Dengan demikian dari hasil refleksi awal diperoleh rata-rata nilai kemampuan pemecahan masalah siswa kelas VIII-A SMP Negeri 1 Sawan belum memenuhi KKM (70). Selain itu, ketuntasan belajar siswa secara klasikal juga belum memenuhi kriteria yang telah ditetapkan.

Pada akhir siklus I siswa diberikan tes kemampuan pe-mecahan masalah yang terdiri dari tiga soal uraian. Dari hasil analisis data diperoleh rata-rata nilai kemampuan pemecahan masalah sebesar 70,05 dengan ketuntasan belajar $68,75 \%$ yaitu hanya 22 siswa yang mampu mencapai KKM (70). Adapun sebaran data mengenai kemampuan pemecahan masalah matematika siswa dapat diperhatikan pada gambar 1.2

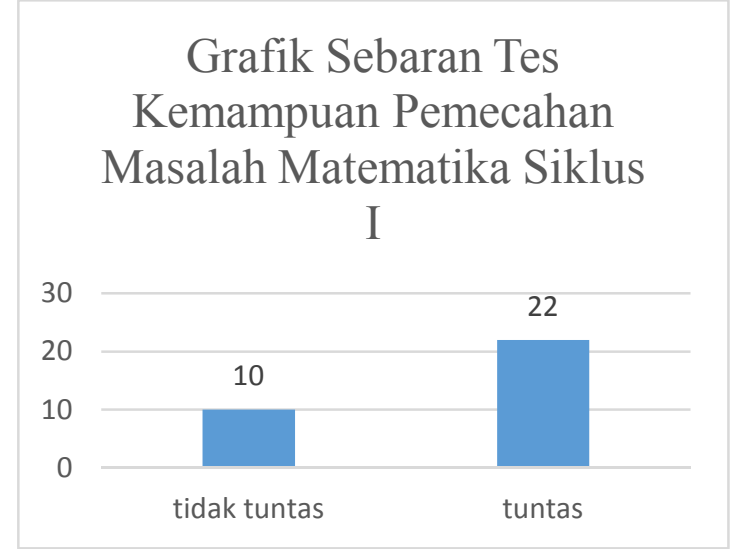

Jurnal Pendidikan dan Pembelajaran Matematika Indonesia | 64 


\section{Gambar 1.2. Grafik Sebaran Tes Kemampuan Pemecahan Masalah Matematika Siklus I}

Berdasarkan hasil analisis data di atas, dapat disimpulkan bahwa pelaksanaan tindakan pada siklus I belum memenuhi indikator keberhasilan yang telah ditetapkan karena ketuntasan belajar siswa secara klasikal belum mencapai $70 \%$. Dengan demikian, beberapa kendala dalam kegiatan pem-belajaran pada Siklus I perlu diperhatikan, sehingga dapat dicarikan solusi sebagai upaya perbaikan pelaksanaan tindakan pada Siklus II. Oleh karena itu, perlu dilakukan refleksi terhadap pelaksanaan tindakan pada Siklus II.

Pada akhir siklus II siswa diberikan tes kemampuan pemecahan masalah yang terdiri dari tiga soal uraian. Dari hasil analisis data diperoleh rata-rata nilai kemampuan pemecahan masalah sebesar 75,26 dengan ketuntasan belajar $78,13 \%$ yaitu 25 siswa sudah mencapai KKM (70). Adapun sebaran data mengenai kemam-puan pemecahan masalah matematika siswa dapat diperhatikan pada gambar 1.3

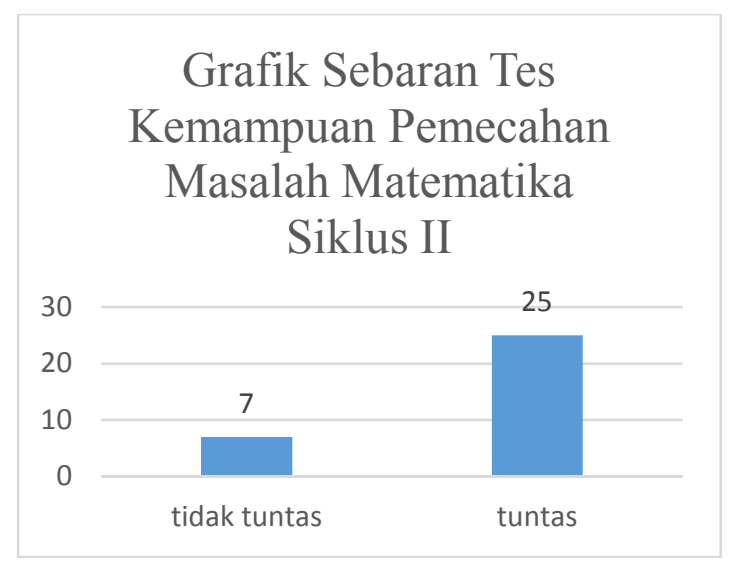

Gambar 1.3. Grafif Sebaran Tes Kemampuan Pemecahan Masalah Matematika Siklus II

Berdasarkan analisis data di atas memperlihatkan bahwa $78,13 \%$ siswa telah mencapai nilai KKM dan rata-rata tes kemampuan pemecahan masalah mate-matika siswa telah mencapai KKM dimana nilai tes kemampuan pemecahan masalah matematika siswa sebesar 75,26 . Artinya, sebagian besar siswa telah mampu memecahkan permasalahan matematika pada materi volume balok, kubus, prisma dan limas yang di bahas pada siklus II.

Pada akhir siklus III siswa diberikan tes kemampuan pemecahan masalah yang terdiri dari tiga soal uraian. Dari hasil analisis data diperoleh rata-rata nilai kemampuan pemecahan masalah sebesar 81,08 dengan ketuntasan belajar $84,38 \%$ yaitu 27 siswa sudah mencapai KKM (70). Adapun sebaran data mengenai kemampuan pemecahan masalah mate-matika siswa dapat diperhatikan pada gambar 1.4 


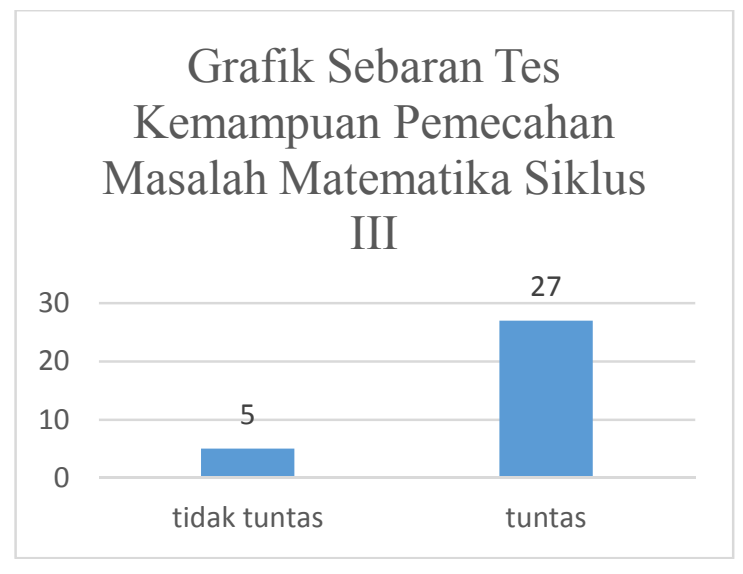

Gambar 4.4. Grafik Sebaran Tes Kemampuan Pemecahan Masalah Matematika Siklus III

Berdasarkan analisis di atas memperlihatkan bahwa $87,50 \%$ siswa telah mencapai nilai KKM dan rata-rata tes kemampuan pemecahan masalah mate-matika siswa siklus III yaitu sebesar 81,08 . Artinya, sebagian besar siswa telah mampu memecahkan permasalahan mate-matika pada materi bangun ruang sisi datar yang dibahas pada siklus III.

Peningkatan rata-rata nilai kemampuan pemecahan masalah matematika siswa ditunjukkan dengan grafik pada Gambar 1.5 di bawah ini

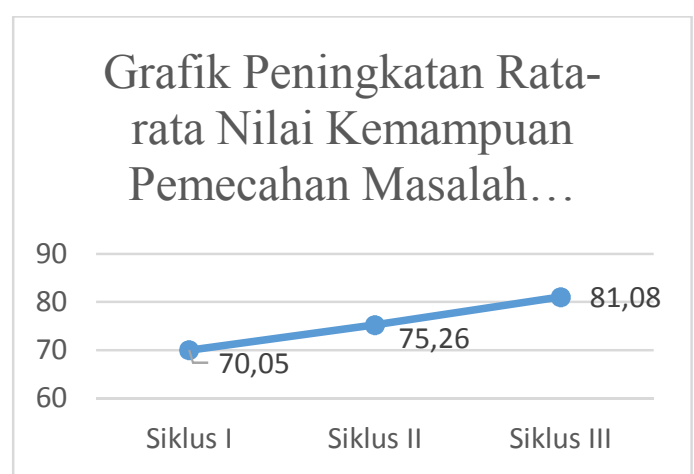

Gambar 1.5. Grafik Peningkatan Rata-rata Nilai Kemampuan Pemecahan Masalah Matematika

Peningkatan rata-rata nilai ke-mampuan pemecahan masalah matematika pada sikklus I ke siklus II sebesar 5,21. Sedangkan peningkatan rata-rata nilai dari siklus II ke siklus III sebesar 5,82 . Sedangkan peningkatan ketuntasan belajar siswa ditunjukkan dengan grafik pada Gambar 1.6 di bawah ini: 


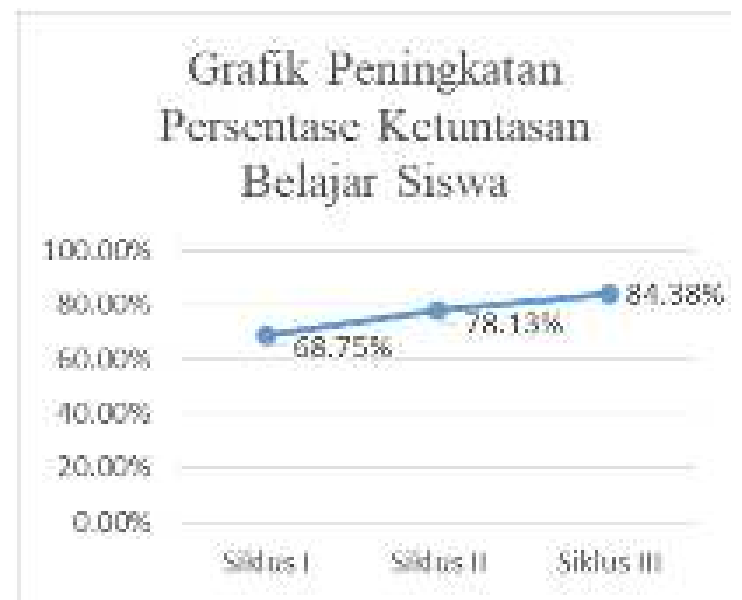

Gambar 1.6. Grafik Peningkatan Persentase Ketuntasan Belajar Siswa

Peningkatan KB dari siklus I ke siklus II sebesar 9,38\%. Sedangkan peningkatan KB dari siklus II ke siklus III sebesar 6,25\%.

Pada akhir pertemuan siklus III, siswa diberikan angket untuk mengetahui bagaimana respon siswa terhadap penerapan model pembelajaran creative problem solving berbantuan portofolio. Data mengenai respon siswa dikumpulkan pada akhir siklus III menggunakan angket respon yang terdiri 15 butir pernyataan.

Sebaran data siswa yang memberikan respon respon sangat positif, positif, cukup, kurang positif dan sangat kurang positif disajikan pada Gambar 1.7 berikut.

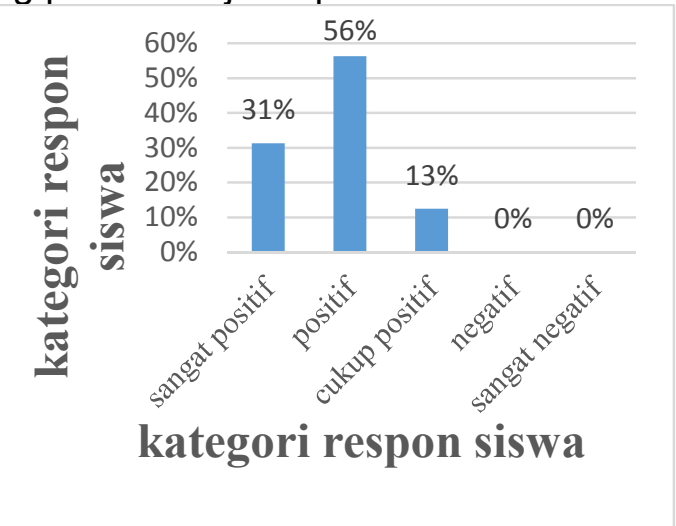

\section{Gambar 1.7. Grafik Sebaran Data Respon Siswa}

Berdasarkan data tersebut diperoleh rata-rata skor respon siswa selama proses pembelajaran adalah 57,41 yang tergolong dalam kategori positif. Sehingga respon siswa terhadap penerapan model pem-belajaran creative problem solving berbantuan portofolio sudah memenuhi indikator keberhasilan.

\section{PEMBAHASAN}

Berdasarkan hasil penelitian yang telah dilaksanakan dalam tiga siklus, terlihat bahwa kemampuan pemecahan masalah siswa terjadi peningkatan dari siklus ke siklus melalui penerapan model pem-belajaran creative problem solving berbantuan portofolio pada materi bangun ruang sisi datar. Hal ini bertolak dari indikator keberhasilan yang telah tercapai dan penerapan model pembelajaran creative provlem solving berbantuan porto-folio yang mampu mengatasi permasalahan yang ada yaitu rendahnya kemampuan pemecahan masalah 
matematika siswa pada kelas VIII-A serta kendala-kendala yang terjadi selama pelaksanaan penelitian sudah dapat ditangani dengan segera melalui refleksi.

Tercapainya peningkatan kemampuan pemecahan masalah matematika siswa dan ketuntasan belajar siswa secara klasikal dapat dilihat dari perbaikan dan pengoptimalan di beberapa langkah-langkah pembelajaran saat model ini diterapkan, berikut adalah penerapan model pembelajaran creative problem solving berbantuan por-tofolio pada materi bangun ruang sisi datar.

Pertama, diskusi kelompok dalam menyelesaikan soal pemecahan masalah membuat siswa memiliki pemikiran yang lebih variatif terhadap masalah yang dikerjakannya, sehingga siswa tidak hanya terpaku pada satu cara saja dalam menyelesaikan masalah matematika. Pada siklus I masih banyak kelompok yang merasa kebingungan dalam pengerjaan LKS karena siswa belum terbiasa mengerjakan permasalahan dengan berbagai kemungkinan cara dan siswa juga masih ragu dengan cara yang digunakan apakah benar atau tidak. Terkadang siswa juga tidak mempertimbangkan kelogisan dalam kehidupan nyata. Tetapi pada siklus II dan III siswa sudah mampu menyampaikan ide-idenya dalam diskusi kelompok serta memberikan pertimbangan kepada siswa lain dalam memutuskan rencana penyelesaian dari permasalahan yang diberikan. Sebagian besar siswa juga sudah mampu memahami masalah dan merencanakan penyelesaian dengan baik.

Kedua, adanya tanggung jawab perseorangan dalam kelompok terhadap cara yang digunakan untuk menyelesaikan masalah membuat siswa lebih aktif dalam mencari solusi dari masalah yang diberikan, sehingga secara tidak langsung berdampak pada pening-katan kemam-puan pemecahan masalah matematika siswa. Adanya tanggung jawab perseorangan dapat dilihat pada tahap menemukan gagasan, yaitu setiap siswa dalam satu kelompok mencari gagasan-gagasan atau cara-cara yang mungkin dalam menyelesaikan permasalahan yang diberikan selanjutnya siswa memilih cara mana yang akan digunakannya berdasar-kan hasil pemikiran anggota-anggota kelompoknya sehingga semua anggota kelompok ikut berperan aktif dalam menyelesaikan permasalahan yang diberi-kan dalam LKS Pada Siklus I, masih beberapa siswa saja yang berperan aktif dalam mengerjakan LKS, namun setelah guru memberikan motivasi kepada siswa dengan menekankan penting-nya bekerja sama, saling bertukar ide, tanggung jawab setiap anggota kelompok dalam melaksanakan diskusi kelompok dan memberikan pertanyaan pancingan bagi siswa untuk dapat mengemukakan gagasannya. Dengan demikian, pada siklus II dan siklus III sebagian besar siswa sudah menunjukkan keaktifannya dalam berpartisipasi untuk mengemukakan gagasangagasannya.

Ketiga, presentasi yang dilakukan siswa di depan kelas disertai dengan sanggahan ataupun gagasan dari siswa yang lainnya, membuat siswa lebih terbiasa dalam mengemukakan ide-ide mereka dimana sebelumnya siswa merasa segan untuk mengemukakan pen-dapatnya. Hal ini mengakibatkan konsep yang mereka temukan menjadi lebih mantap dari sebelumnya.

Keempat, semakin sering siswa menyelesaikan masalah yang berbentuk soal nonrutin, siswa memiliki lebih banyak pengalaman dalam merumuskan gagasan atau solusi yang tepat untuk memecahkan masalah. Walaupun pada siklus I masih terdapat beberapa kendala dalam pengerjaan maupun pengumpulannya, seperti siswa kurang tepat waktu dalam pengumpulannya, kelengkapan maupun kualitas pekerjaan masih kurang serta masih ada siswa yang menyalin langsung pekerjaan siswa lainnya. Namun hal ini bisa diatasi oleh guru dan peneliti pada Siklus II dan Siklus III, yaitu dengan memperhatikan feedback (komentar) yang diberikan guru kepada siswa pada setiap portofolio mengenai kekurangan-kekurangan siswa tersebut yang diharapkan agar segera diperbaiki dan menginformasikan jika ada cara pe-nyelesaian yang sama dari awal hingga akhir maka akan diberikan tugas tambahan. Hal ini dilakukan untuk me-minimalisir siswa yang menyalin pekerjaan siswa lainnya. Dengan dilakukannya perbaikan-perbaikan pada siklus II dan siklus III tampak bahwa siswa telah 
mampu memperbaiki dirinya, dilihat dari hasil pekerjaan dari masing-masing siswa. Sikap disiplin, kerja keras, dan tanggung jawab yang dimiliki oleh siswa atas masing-masing portofolionya membantu siswa untuk lebih terlatih dalam memecahkan masalah matematika.

Melalui perbaikan-perbaikan yang dilakukan oleh guru dalam proses pembelajaran dari siklus I dan siklus II membuat siswa mampu menyelesaikan permasalahan matematika dengan tidak terpaku pada satu cara saja atau dengan kata lain siswa mampu menyelesaikan permasalahan dengan cara mereka sendiri. Sehingga pada siklus III tidak terdapat permasalahan yang berarti. Penerapan model pembelajaran creative problem solving berbantuan portofolio di kelas VIII-A SMP Negeri 1 Sawan berjalan dengan lancar, sudah sesuai dengan teori karena kendala-kendala yang dihadapi mampu diselesaikan melalui refleksi setiap proses pembelajaran maupun setiap siklusnya sehingga kemampuan pemecahan masalah matematika siswa telah mengalami peningkatan dari siklus ke siklus.

Hal ini sejalan dengan penelitian yang dilakukan oleh I Made Budiadnyana. Hal yang mendukung dari penelitian ini yaitu penerapan model creative problem solving memiliki pengaruh positif terhadap kemampuan pemecahan masalah matematika dan juga siswa yang mengikuti model pembelajaran creative problem solving lebih mampu melaksanakan penyelesaian masalah menggunakan prosedur solusi yang benar sehingga hasil yang diperoleh juga benar. Selain itu penelitian ini juga sejalan dengan hasil penelitian Putu Rini Handayani. Hal yang mendukung dari penelitian ini yaitu asesmen portofolio berpengaruh positif terhadap kemampuan pemecahan masalah matematika siswa. Selain terjadi peningkatan kemampuan pemecahan masalah matematika siswa, penerapan model pembelajaran creative problem solving berbantuan portofolio juga mendapatkan respon positif dari siswa. Dengan demikian, hasil penelitian ini telah memenuhi semua indicator keberhasilan yang telah ditetapkan. Jadi dapat disimpulkan penelitian sudah berhasil.

\section{SIMPULAN DAN SARAN SIMPULAN}

Berdasarkan hasil penelitian dan pembahasan yang telah dipaparkan di bab sebelumnya, dapat disimpulkan beberapa hal sebagai berikut. (1) Secara umum kemampuan pemecahan masalah matematika siswa kelas VIII-A di SMP Negeri 1 Sawan mengalami peningkatan dari tiap siklus. Peningkatan ini terjadi karena berbagai tindakan yang telah dilakukan guru dan peneliti dalam mengatasi kendala-kendala yang mempengaruhi peningkatan kemampuan pemecahan masalah matematika siswa yaitu: 1) Semakin seringnya siswa menyelesaikan masalah yang berbentuk soal non-rutin, siswa memiliki lebih banyak pengalaman dalam me-rumuskan gagasan atau solusi yang tepat untuk memecahkan permasalahan matematika. 2) pemberian penjelasan kepada siswa tentang langkah-langkah pemecahan masalah menurut Polya dapat membuat solusi dari masalah yang diselesaikan siswa menjadi lebih optimal. 3) Adanya tanggungjawab perseorangan dalam kelompok terhadap masalah yang berbeda membuat siswa lebih aktif dalam mencari solusi dari masalah yang diberikan, sehingga secara tidak langsung berdampak pada peningkatan kemampuan pemcahan masalah matematika siswa. 4) Diskusi kelompok membuat siswa memiliki pemikiran yang lebih variatif terhadap masalah yang dikerjakannya, sehingga siswa tidak hanya terpaku pada satu cara saja dalam menyelesaikan masalah matematika. 5) Presentasi yang dilakukan siswa di depan kelas disertai dengan sanggahan ataupun gagasan dari siswa yang lainnya, membuat siswa lebih terbiasa dalam mengemukakan ide-ide mereka dimana sebelumnya siswa merasa segan untuk mengemukakakan pendapat-nya. Hal ini mengakibatkan konsep yang mereka temukan menjadi lebih mantap dari sebelumnya. (2) Tanggapan siswa yang dikumpulkan melalui angket respon siswa yaitu rata-rata skor respon siswa telah berada dalam kategori positif. Berdasarkan persentase banyaknya siswa yang memberikan respon positif $56 \%$ (18 orang), cukup positif $13 \%$ (4 orang) dan sangat positif $31 \%$ (10 orang). Secara keseluruhan respon siswa terhadap penerapan model pembelajaran 
creative problem solving berbantuan portofolio tergolong positif dengan rata-rata respon siswa sebesar 57,41. Hal ini sesuai dengan indikator keberhasilan dalam penelitian ini.

\section{SARAN}

Berdasarkan hasil penelitian ini, disam-paikan beberapa saran sebagai berikut.

Diharapkan penerapan model pembelajaran creative problem solving berbantuan portofolio ini bisa dijadikan alternative pembelajaran dalam melaksa-nakan pembelajaran matematika untuk mengatasi permasalahan dalam kemam-puan pemecahan masalah matematika.

Disarankan kepada pembaca yang agar memperhatikan per-masalahan yang ditemukan selama pelaksanaan tindakan sebagai bahan pertimbangan untuk perbaikan dan penyempurnaan pelaksa-naan tinda-kan selanjutnya.

\section{UCAPAN TERIMAKASIH}

1. Bapak Dr. I Made Sugiarta, M.Si. selaku pembimbing akademik sekaligus pembimbing I yang telah memberikan arahan serta bimbingan-nya dalam penyusunan proposal ini.

2. Bapak Prof. Dr. I Gusti Putu Suharta, M.Si. selaku pembim-bing II yang telah memberikan arahan serta bimbingan-nya dalam penyusunan proposal ini.

3. Rekan-rekan mahasiswa dan mahasiswi Program Studi Pendidikan Matematika, yang telah memberikan informasi terkait penulisan makalah ini hingga dapat diselesaikan tepat pada waktunya.

\section{DAFTAR PUSTAKA}

Budiadnyana, I.M. 2017. "Pengaruh Penerapan Model Pembe-lajaran Creative Problem Solving (CPS) dan Model Pembelajaran Inkuiri Terbimbing terhadap Kemampuan Pemecahan Masalah dan Sikap Matematika Peserta Didik Kelas XI SMAN 6 Denpasar Tahun Pelajaran 2016/2017". Tesis (tidak diterbit-kan). Jurusan Pendidikan Matematika, Universitas Pendidikan Ganesha.

Creative Education Foundation. 2018. Creative Problem Solving. Tersedia di :http://www.Creativeeducationfoundation.org/creative-problem-solving/the-cpsprocess/. Scituate: MA (diakses 28 Desember 2017)

Djamarah, Syaful Bhari dan Zain Aswan. 2006. Strategi Belajar Mengajar. Jakarta: Rineka Cipta.

Febru, Erna. 2011. Asesmen dan Evaluasi. Malang: Aditya Media Publishing.

McNiff, J. 2002. Action Research: Principles and Practice. London: Routledge.

National Council of Teacher of Mathe-matics (NCTM). 2000. Principles and Standards for School Mathematics. Reston, VA NCTM. Hal 52

Pepkin. 2004. Creative Problem Solving in Math. Tersedia di :http://www.uh.edu.hti/w/2004/v02/04.html/. (diakses 4 Janu-ari 2018)

Polya, G. 1973. How to Solve It: a New Aspect of Mathematics Method $2^{\text {nd }}$ Edition. New Jearsey: Princeton University Press.

Santoso, Budi. 2007. Penilaian Portofolio Dalam Matematika. Jurnal Pendidikan Matematika Vol.1 No.2. http://ejournal.unsri.ac.id/index.php/jpm/article/view/811/224 (diakses 10 Januari 2018)

Suherman, Erman (dkk).2003.Strategi Pembelajaran Matematika Konteporer.Bandung: Jurusan Pendidikan Matematika FMIPA UPI. 